\title{
Effects of Monsoon Rainfalls on Surface Water Quality in a Mountainous Watershed under Mixed Land Use
}

\author{
Kyeong-Won Jo ${ }^{1}$, Hyun-Ju Lee ${ }^{1}$, Ji-Hyung Park ${ }^{1 *}$ and Jeffrey S. Owen ${ }^{1,2}$ \\ ${ }^{1}$ Department of Forest Environment Protection, College of Forest \& Environmental Sciences, $K$ \\ angwon National University, Chuncheon, 200-701, Korea \\ ${ }^{2}$ Department of Environmental Science, College of Natural Sciences, Kangwon National University, \\ Chuncheon, 200-701, Korea
}

(Received July 1, 2010; Revised September 26, 2010; Accepted September 27, 2010)

\section{토지이용이 다변화된 산림 유역의 수질에 미치는 몬순 강우의 영향}

\author{
조경원 ${ }^{1} \cdot$ 이현주 ${ }^{1} \cdot$ 박지형 ${ }^{1 *} \cdot$ Jeffrey S. Owen ${ }^{1,2}$ \\ 1강원대학교 산림환경과학대학 산림환경보호학과 \\ 2강원대학교 자연과학대학 환경과학과 \\ (2010년 7월 1일 접수; 2010년 9월 26일 수정; 2010년 9월 27일 수락)
}

\begin{abstract}
To provide baseline information essential for assessing environmental impacts of monsoon rainfalls in a mountainous watershed under mixed land use, we investigated spatiotemporal variations in water quality using a combined approach of seasonal water quality survey and intensive storm samplings. Biannual water sampling at nine locations encompassing major land use types showed generally lower electrical conductivity and $\mathrm{Cl}^{-}$concentrations during the typical wet period compared to the dry period, indicating rainfall-induced dilution of dissolved ions. Total metal concentrations, however, were significantly higher during the monsoon period, probably associated with rainfall-induced increases in suspended sediments. Intensive storm sampling during a small monsoon rainfall event $(18 \mathrm{~mm})$ and an extreme event $(452 \mathrm{~mm})$ showed rapid changes in both suspended sediments and dissolved solutes in an agricultural stream draining the Haean Basin where arable lands have expanded rapidly over the recent decades. By contrast, a nearby forest stream derived from North Korea showed little responses to the small event compared to larges changes during the extreme event. In the agricultural stream total $\mathrm{Pb}$ concentrations showed significant positive relationships with suspended sediments. Although limited sampling frequency and locations require a cautious interpretation, the overall results suggest that expansion of agricultural fields in steep mountainous watersheds can increase the susceptibility of soil erosion and its off-site environmental impacts under increasing rainfall variability and extremes.
\end{abstract}

Key words : Climate variability; Monsoon rainfalls; Mountainous watersheds; Surface water quality; Trace metals

\section{INTRODUCTION}

Although mountains represent only one fifth of the world terrestrial surface, half of the human population depends in various ways on mountain ecosystems
(Körner et al., 2005). Providing water resources is one of the most important ecosystem services provided by mountains. The contribution of mountainous areas to total discharge in the world's major river basins was assessed to be disproportionately high, accounting for

* Corresponding Author: Ji-Hyung Park (jihyungpark@kangwon.ac.kr) 
$63 \%$ of total discharge, compared to the extent of mountain areas (32\%) (Viviroli et al., 2003). On a global scale, areas with mountainous terrain also contribute a large fraction of the total supply of sediments and organic carbon to the oceans (Milliman and Syvitski, 1992; Goldsmith et al.,2008; Hilton et al.,2008). Mountainous watersheds, in addition to serving as important source areas for dissolved and particulate materials transported to coastal and marine environments, are known to be sensitive to climate change (Körner et al., 2005; Park et al.,2010).

Model predictions of greater variability in precipitation patterns and more frequent extreme events have implications regarding soil erosion in mountainous watersheds and downstream sediment transport. An improved understanding is needed regarding whether increased rates of soil erosion rates will result as precipitation amount or precipitation intensity increase (Asselman et al., 2003). Because of the complex role that suspended sediments have in affecting speciation, transport, and bioavailability of metals, a trend towards increased precipitation variability and more frequent extreme events could also affect metal concentrations and export to aquatic ecosystems in this region. Many studies have shown that suspended sediments play a crucial role in the export of metals from watersheds and metal speciation between dissolved and particulate phases in surface waters due to its strong complex building with adsorptive metals (Horowitz, 1991; Shafer et al., 1997; Point et al., 2007).

Along with other regions of the globe, many watersheds in northeast Asia are also characterized by steep slopes and summer monsoonal rainfall (Meybeck et al., 2001; Kim et al., 2002; Park et al., 2010). Climate modeling studies for the Korean peninsula have shown that increases in precipitation and frequency of extreme events are likely to occur in the future (Boo et al., 2006; Im et al., 2007). A recent study by Chang et al. (2009) discussed flood risk management in Gangwon Province, South Korea. Using a multiple regression approach, their study suggested that flood damage in the province was closely related to daily precipitation amount. With an increase in precipitation intensity or total precipitation amounts, greater damage from landslides on steep mountain slopes and flooding would be expected.

Some mountainous areas in Korea are undergoing changes in land use as the amount of land used for either agriculture or residential use increases. In Korea, mountainous areas provide necessary storage capacity for flood prevention, drinking water and recreational water use. Although a number of studies have carried out water quality monitoring in large rivers and lakes (Kim et al., 2000; Park et al., 2010), few studies have focused on the interactions between climate change, monsoon rainfall, and land use change in Korea. We conducted a study to provide baseline information essential for assessing the vulnerability of stream water quality to land use changes in this region of Korea. A second objective of the study was to investigate shortterm changes in stream chemistry occurring during precipitation events and compare these changes to seasonal patterns in stream chemistry in our study streams with particular focus on suspended sediments and trace metals.

\section{MATERIALS AND METHODS}

\subsection{Study site and sampling}

The study area is the Lake Soyang Watershed located in Gangwon Province, South Korea ( $37^{\circ} 56^{\prime} \mathrm{N}, 127^{\circ}$ 49' E; elevation ranging from $180-1708 \mathrm{~m}$; Fig. 1). The annual mean temperature averaged $10.9^{\circ} \mathrm{C}$ and the annual precipitation $1,267 \mathrm{~mm}$ over the last decade (Park et al., 2010). The landscape in the study area is typically mountainous, with mixed land use patterns across the watershed. Forested land comprises $85 \%$ of the land cover $\left(2,694 \mathrm{~km}^{2}\right)$, while croplands account for a relatively small portion $(4.7 \%)$ of the whole watershed area, with 5,253 ha of paddies and 7,313 ha of fields (Ministry of Environment, 2007). Despite the relatively small land cover, expanding agricultural fields on steep terrain have been suggested as a major source of soil erosion in the North Han River Watershed. Over $30 \%$ of the fields are located on steep slopes $\breve{S} 15^{\circ}$ (Ministry of Environment, 2007). Agricultural fields also export large amounts of nutrients due to the high rate of fertilizer application and pen-type livestock farming, resulting in recurrent eutrophication of the Lake Soyang (Park et al., 2010). A few small cities and towns (2,228 ha) with the total population of $\sim 75,000$ are scattered throughout the region. Forests in the area are temperate mixed deciduous forests. The bedrock in the region consists of gneisses and granites and Cambisols represent the dominant soil type. The study area is characterized by a temperate climate with summer monsoonal precipitation between June and August which contributes more than 60 per cent of the annual 


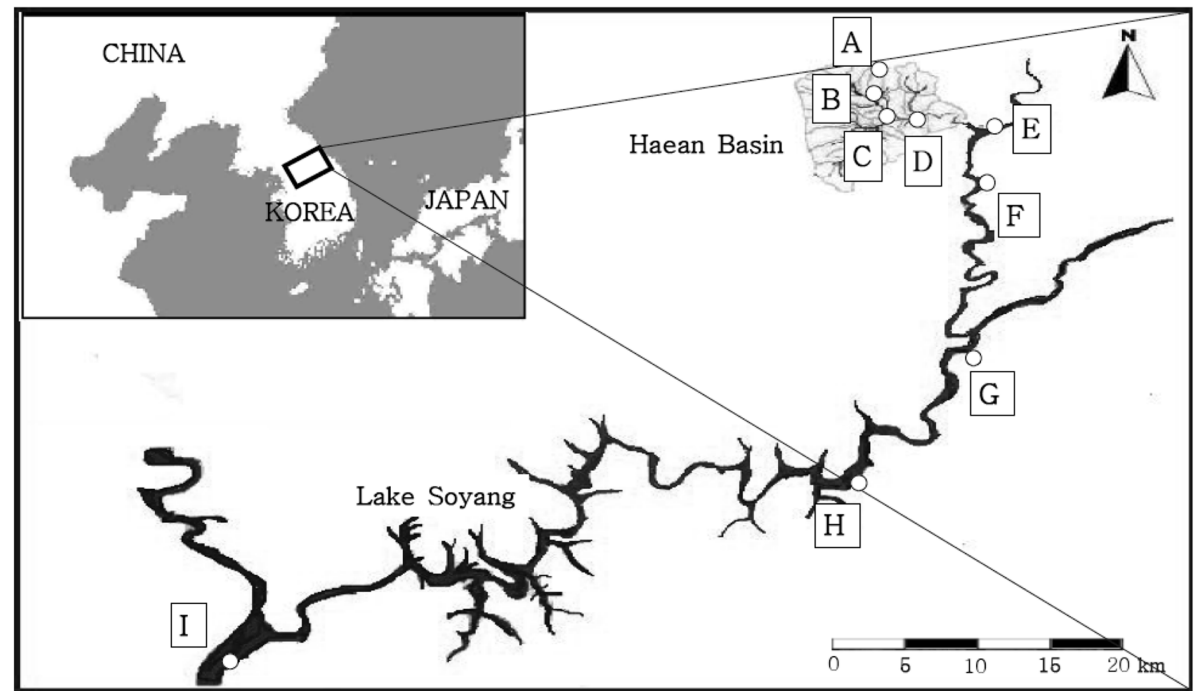

Fig. 1. Location of sampling stations. Refer to the descriptions in the text of Methods for more details on land use patterns in the study area.

Table 1. Watershed characteristics for the study streams

\begin{tabular}{ccccc}
\hline \hline \multirow{2}{*}{ Site } & \multicolumn{2}{c}{ Coordinates } & Distance from site A (km) & Land use \\
\cline { 2 - 5 } & Latitude & Longitude & - & forest \\
\hline $\mathrm{A}$ & $38^{\circ} 18^{\prime} 48^{\prime \prime} \mathrm{N}$ & $128^{\circ} 08^{\prime} 29^{\prime \prime} \mathrm{E}$ & - & \\
$\mathrm{E}$ & $38^{\circ} 16^{\prime} 48^{\prime \prime} \mathrm{N}$ & $128^{\circ} 08^{\prime} 29^{\prime \prime} \mathrm{E}$ & 1.8 & \\
$\mathrm{~B}$ & $38^{\circ} 18^{\prime} 03^{\prime \prime} \mathrm{N}$ & $128^{\circ} 08^{\prime} 05^{\prime \prime} \mathrm{E}$ & 3.1 & mixed agricultural, \\
$\mathrm{C}$ & $38^{\circ} 17^{\prime} 26^{\prime \prime} \mathrm{N}$ & $128^{\circ} 08^{\prime} 26^{\prime \prime} \mathrm{E}$ & 4.0 & residential \\
$\mathrm{D}$ & $38^{\circ} 17^{\prime} 05^{\prime \prime} \mathrm{N}$ & $128^{\circ} 08^{\prime} 48^{\prime \prime} \mathrm{E}$ & 15.2 & \\
$\mathrm{~F}$ & $38^{\circ} 15^{\prime} 44^{\prime \prime} \mathrm{N}$ & $128^{\circ} 12^{\prime} 35^{\prime \prime} \mathrm{E}$ & 45.2 & urban \\
$\mathrm{G}$ & $38^{\circ} 05^{\prime} 22^{\prime \prime} \mathrm{N}$ & $128^{\circ} 10^{\prime} 58^{\prime \prime} \mathrm{E}$ & 56.0 & \\
\hline $\mathrm{H}$ & $37^{\circ} 00^{\prime} 07^{\prime \prime} \mathrm{N}$ & $128^{\circ} 06^{\prime} 33^{\prime \prime} \mathrm{E}$ & 125.2 & \\
$\mathrm{I}$ & $37^{\circ} 52^{\prime} 15^{\prime \prime} \mathrm{N}$ & $127^{\circ} 41^{\prime} 24^{\prime \prime} \mathrm{E}$ &
\end{tabular}

precipitation.

To compare water chemistry between wet and dry periods, water samples were collected two times (August 2007 and May 2008) at nine sampling sites. The sampling sites were located within the Lake Soyang Watershed from one of the smaller headwaters (site A) to a lake site downstream of Chuncheon City (site I) along a stream distance of $125 \mathrm{~km}$ (Fig. 1; Table 1). The sites B, C, and D are located along downstream reaches of the Mandae Stream, a stream draining agricultural areas (hereafter denoted as 'agricultural stream') in a bowl-shaped basin (Haean Basin), a few km south of the border between South and North Koreas. Rapid expansion of intensive farming on steep hillslopes over the recent decades has transformed the otherwise well forested mountainous watershed into a major source of soil erosion. The current land use in the basin $(6,153$ ha) includes forests (58.6\%), agricultural fields (27.5\%) and paddies (8.7\%) (Yanggu-Gun, 2008). As in other parts of the Lake Soyang Watershed, high rates of both organic and inorganic fertilizer application and pentype livestock farming on highland slopes release large amounts of nutrients to agricultural streams.

The site A is a headwater forest stream tributary to the Mandae Stream, which meets a relatively large stream (the uppermost stream of the Inbuk River) derived from North Korea $\sim 100 \mathrm{~m}$ downstream of the site E. We used sampling sites A and E to represent 
patterns in the upper streams water chemistry in the watershed, the most distant from possible residential and agricultural impacts. Despite the lack of information on pollution sources along upstream reaches of the site $\mathrm{E}$ in North Korea, our routine water quality monitoring has supported our assumption that the upstream areas have a limited number of pollution sources. Sites $\mathrm{B}$ through D and sites F through I were used to represent downstream patterns in stream chemistry including impacts from residential and agricultural land use.

We also conducted more intensive water sampling at the $\mathrm{D}$ and $\mathrm{E}$ sites during two different precipitation events. During June 2007, we collected stream grab samples to monitor changes in stream chemistry and suspended solids at approximately 2 hour intervals during an $18 \mathrm{~mm}\left(2.25 \mathrm{~mm} \mathrm{hr}^{-1}\right)$ rain event. In August 2007, we monitored stream chemistry during the later phase of an extreme rain event, a storm with total rainfall of $452 \mathrm{~mm}$ in three days $\left(5.14 \mathrm{~mm} \mathrm{hr}^{-1}\right)$.

Water samples were collected using clean grab sample techniques with pre-cleaned polyethylene bottles. During water sampling, in-situ water quality parameters were measured, including water temperature, $\mathrm{pH}$, and conductivity. Immediately after water sampling, a portion of each sample $(50 \mathrm{ml})$ was filtered on-site using a syringe filter $(25 \mathrm{~mm}$ Puradisc syringe $0.45 \mu \mathrm{m}$ filter, Whatman) attached to a $50 \mathrm{ml} \mathrm{PP} / \mathrm{PE}$ syringe (Aldrich) based on a simplified filtering method developed for trace metal analysis at remote sites (Shiller 2003). A portion of each sub-sample was preserved with ultra-pure $\mathrm{HNO}_{3}$ for dissolved metal analysis. An additional sub-sample (unfiltered) was kept for total suspended solids (TSS) measurement and determination of total metal concentrations.

\subsection{Chemical and data analyses}

Samples were analyzed for TSS, UV absorbance at $254 \mathrm{~nm}\left(\mathrm{UVA}_{254}\right.$; Libra S32P), and dissolved anion concentrations (Dionex-320) either at the Environmental Biogeochemistry Laboratory or Central Laboratory of Kangwon National University. TSS was measured after filtering using a pre-combusted GF/F filter (Whatman). For determination of total metal concentrations, unfiltered samples $(50 \mathrm{ml})$ were acid-digested with ultra-pure $\mathrm{HNO}_{3}$ using an EPA method for acid-recoverable metal analysis (Creed et al., 1994). Measurement of $\mathrm{Al}, \mathrm{Fe}, \mathrm{Mn}, \mathrm{As}, \mathrm{Cu}$ and $\mathrm{Pb}$ concentrations was conducted by ICP-MS (Agilent $7500 \mathrm{cs}$ ) at International Environmental Research Center, Gwangju Institute of
Science and Technology. To ensure data quality, the laboratory followed a strict QA/QC program, including replicate sample analysis and analysis of reference standards within each batch of samples. Due to nonnormal distributions for most dissolved and total metal concentrations, we used two-sided Wilcoxon rank-sum tests to compare differences in concentrations between wet and dry seasons. Hourly precipitation data were obtained from an automatic weather station located within the Punch Bowl Watershed (data source: Korea Meteorological Administration). Discharge data were obtained from a gauging station along the Inbuk River near the sampling location F (data source: WAMIS database managed by Han River Flood Control Office).

\section{RESULTS AND DISCUSSION}

\subsection{Seasonal comparison of stream water chem-} istry in the Lake Soyang Watershed

Across the sampling locations in the Lake Soyang Watershed distinct seasonal differences were observed for some of the measured water quality parameters (Fig. 2; Table 2). Conductivity, as a measure of dissolved ions, was lower in wet-season (August 2007) samples at all sites except the agricultural stream ' $\mathrm{B}$ ' (Fig. 2). $\mathrm{Cl}^{-}$concentrations showed similar spatiotemporal patterns, ranging from 1.8 to 12.1 and 1.8 to 4.6 $\mathrm{mg} \mathrm{L}^{-1}$ for the May and August sampling dates, respectively. These distinct seasonal differences might reflect the dilution effect for dissolved ions during the monsoon period. For the concentrations of $\mathrm{NO}_{3}{ }^{-}$and $\mathrm{NH}_{4}{ }^{+}$ seasonal patterns were variable depending on sampling locations. $\mathrm{NO}_{3}{ }^{-}$and $\mathrm{NH}_{4}{ }^{+}$concentrations were especially higher in August samples at the agricultural stream B and the urban river E. This might be partly explained by rainfall-induced increases in $\mathrm{N}$ inputs through either agricultural or urban runoff. We observed a general spatial pattern where the concentrations of dissolved solutes were the lowest in streams A and E (forest streams) and highest in mid-section stream and river reaches under strong influence of agricultural runoff and somewhat lower in streams farther downstream (Fig. 2).

Dissolved and total metal concentrations were generally higher during the wet period (Table 2). Although significant differences between sampling dates were also seen in concentrations of dissolved metals, seasonal differences were much more apparent for total metals (two-sided Wilcoxon rank sum test, $p<0.05$ ). On 


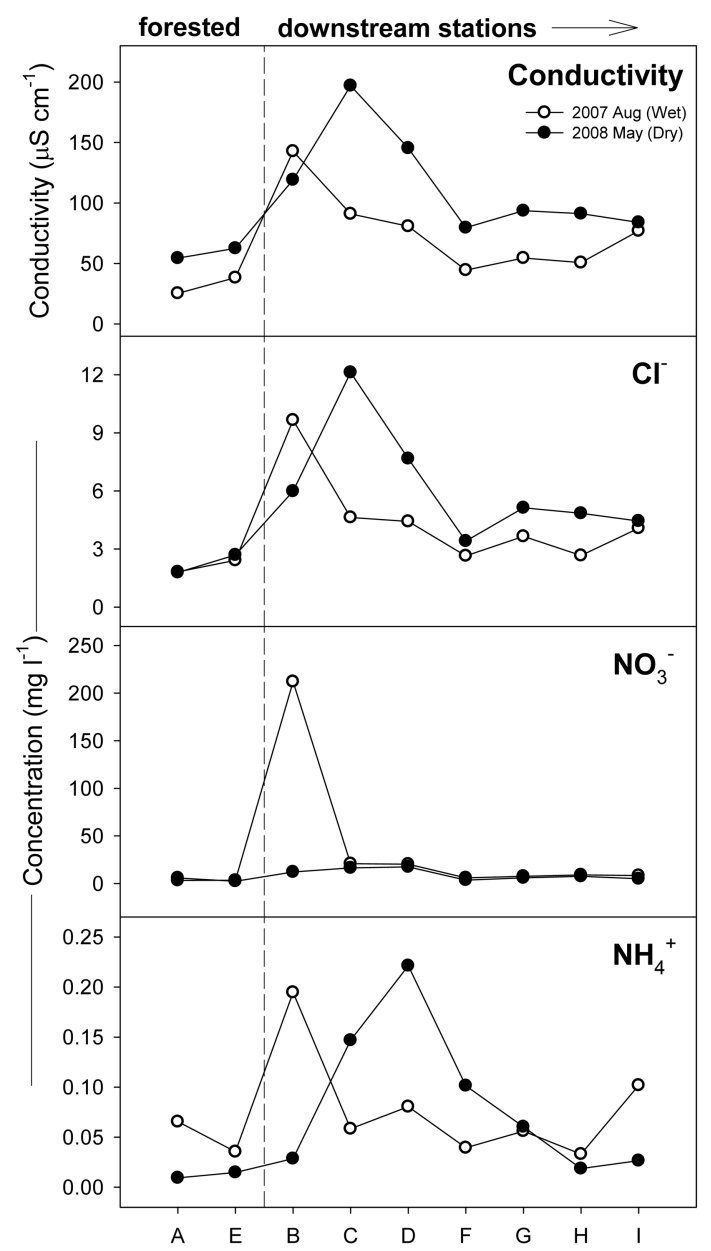

Fig. 2. Seasonal comparison of conductivity and $\mathrm{Cl}^{-}, \mathrm{NO}_{3}{ }^{-}$ and $\mathrm{NH}_{4}{ }^{+}$concentrations for the 9 streams (location of stations A-I as in Fig. 1).

average, concentrations of total $\mathrm{Al}, \mathrm{Fe}, \mathrm{Mn}, \mathrm{Pb}$ and $\mathrm{Cu}$ were much higher in August than May. The differences between the total and dissolved concentrations, which are accounted for by particulate concentrations, were also more evident in August (Table 2). The most significant differences were observed for metals with high adsorption capacity, such as $\mathrm{Al}$ and $\mathrm{Pb}$. For example, total $\mathrm{Al}$ concentrations ranged from 36 to $445 \mu \mathrm{g} \mathrm{Al} \mathrm{\textrm {L } ^ { - 1 }}$ during the dry season (May) and from 512 to $12377 \mu \mathrm{g}$ $\mathrm{Al} \mathrm{L}{ }^{-1}$ during the wet season (August). Dissolved Al concentrations showed relatively small seasonal differences, ranging from 7 to $201 \mu \mathrm{g} \mathrm{Al} \mathrm{L}{ }^{-1}$ and from 37 to $139 \mu \mathrm{g} \mathrm{Al} \mathrm{L^{-1 }}$ during the dry and wet seasons, respectively.

For dissolved metal concentrations, seasonal differ-
Table 2. Concentrations of selected metals for all sampling stations during the wet (August 2007) and dry (May 2008) seasons (mean \pm standard error, $\mathrm{N}=9$ ). Difference between two seasons significant at ${ }^{*} p<0.05,{ }^{* *} p<0.01,{ }^{* * *} p<0.001$, respectively

\begin{tabular}{|c|c|c|c|}
\hline \multirow{2}{*}{ Metal } & \multirow{2}{*}{ Phase } & $\begin{array}{c}\text { Wet season } \\
\text { (August 2007) }\end{array}$ & $\begin{array}{l}\text { Dry season } \\
\text { (May 2008) }\end{array}$ \\
\hline & & \multicolumn{2}{|c|}{$\mu \mathrm{g} \mathrm{L}^{-1}$} \\
\hline \multirow[t]{2}{*}{$\mathrm{Al}$} & Total $* * *$ & $3190 \pm 1216$ & $149 \pm 45$ \\
\hline & Dissolved* & $81 \pm 12$ & $47 \pm 21$ \\
\hline \multirow[t]{2}{*}{ As } & Total** & $0.90 \pm 0.22$ & $0.23 \pm 0.03$ \\
\hline & Dissolved* & $0.22 \pm 0.03$ & $0.29 \pm 0.02$ \\
\hline \multirow[t]{2}{*}{$\mathrm{Cu}$} & Total** & $2.14 \pm 0.45$ & $0.72 \pm 0.09$ \\
\hline & Dissolved** & $0.97 \pm \theta .05$ & $0.55 \pm 0.04$ \\
\hline \multirow[t]{2}{*}{$\mathrm{Fe}$} & Total*** & $2408 \pm 715$ & $77 \pm 21$ \\
\hline & Dissolved** & $66 \pm 12$ & $16 \pm 5$ \\
\hline \multirow[t]{2}{*}{$\mathrm{Mn}$} & Total**. & $74 \pm 24$ & $11 \pm 3$ \\
\hline & Dissolved* & $20 \pm 5$ & $6 \pm 2$ \\
\hline \multirow[t]{2}{*}{$\mathrm{Pb}$} & Total $* *$ & $4.95 \pm 1.92$ & $0.63 \pm 0.25$ \\
\hline & Dissolved** & $0.19 \pm 0.03$ & $0.61 \pm 0.14$ \\
\hline
\end{tabular}

ences were not striking, consistent with previous studies showing that the dissolved fraction of metal concentration makes up a small portion of the total concentration (Martin and Meybeck, 1979; Point et al., 2007). For $\mathrm{Al}, \mathrm{Fe}, \mathrm{Mn}, \mathrm{Pb}$, and $\mathrm{Cu}$, particulate metal phases were clearly the most important component of total concentrations and are likely controlled by interactions with suspended sediments (Horowitz 1991). The major vector of metal transport is downstream suspended sediment movement and metallic elements which would otherwise be stored in the terrestrial component of the watershed are exported to downstream ecosystems, including floodplain deposits and reservoirs supplying drinking water.

\subsection{Short-term water quality changes during monsoon rainfall events}

For two contrasting rainfall events, short-term water quality changes were compared in the polluted agricultural stream (D) and the forest stream derived from North Korea (E) to examine land use effects on water quality responses to monsoon rainfalls with different intensity and duration. During the first monsoon event in June (18 mm), dramatic, concurrent increases in TSS and $\mathrm{UVA}_{254}$ were observed in the agricultural stream (site D; Fig. 3), although this small event did not result in any noticeable change in the flow of the Inbuk River downstream of the site $\mathrm{E}$ (mean flow: $1.96 \mathrm{~m}^{3} \mathrm{~s}^{-1}$ ). In 

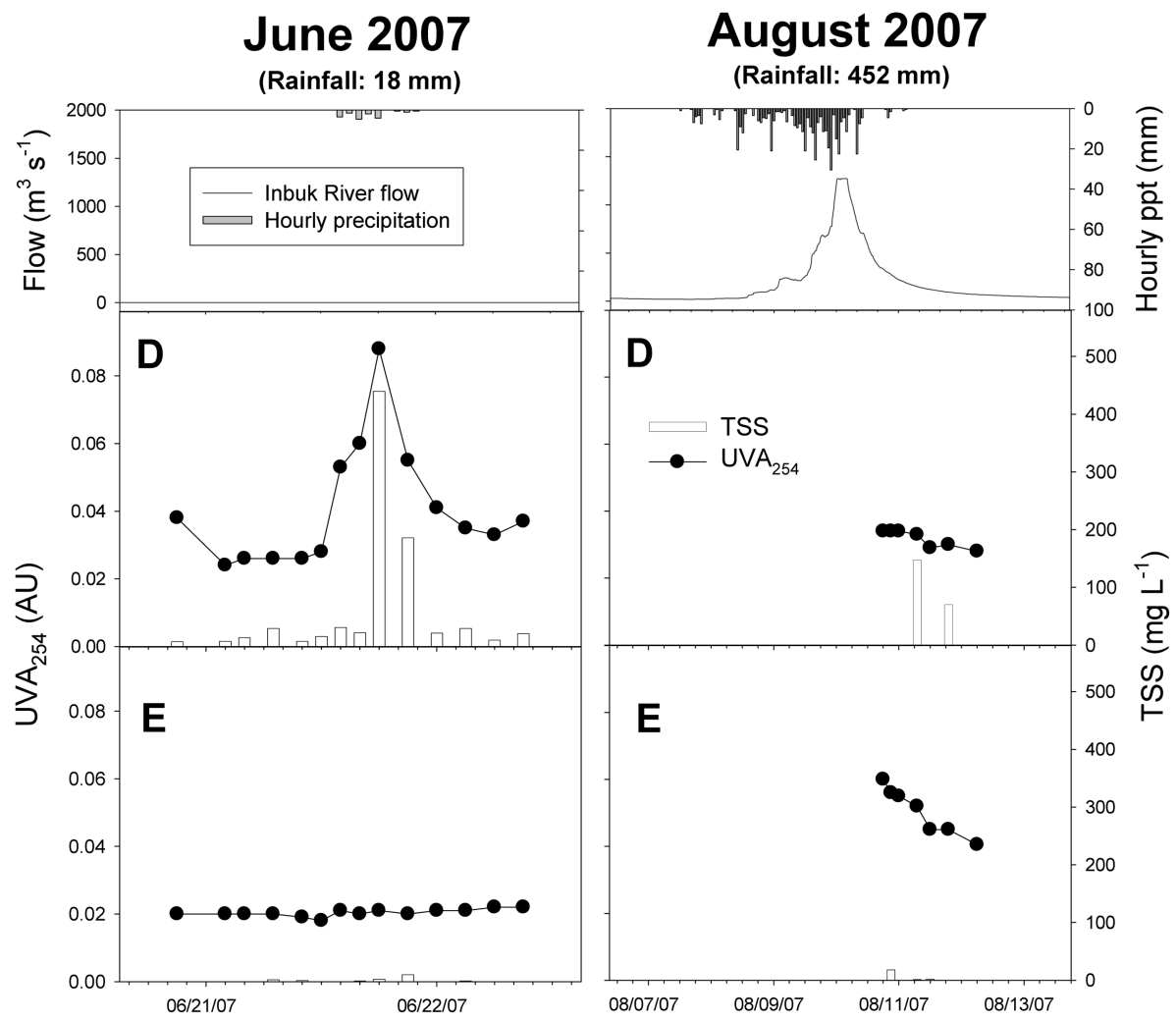

Fig. 3. Short-term changes in concentrations of TSS $\left(\mathrm{mg} \mathrm{L}^{-1}\right)$ and $\mathrm{UVA}_{254}$ intensities (AU) in the agricultural (site D) and forest (site E) streams during two storm events.

contrast, TSS concentrations and $\mathrm{UVA}_{254}$ intensities in the forest stream (site E) changed very little during the June event. The August event sampling captured the later phase of rapid water quality changes in response to rapid changes in runoff during the extreme rainfall event (452 mm for 3 days; Fig. 3). During the peak flow period of this extreme rainfall event, the flow of the Inbuk River reached $1272.94 \mathrm{~m}^{3} \mathrm{~s}^{-1}$ from the preevent flow at $19.59 \mathrm{~m}^{3} \mathrm{~s}^{-1}$. Although we could not measure rising and peak concentrations over the course of the event, TSS concentrations and $\mathrm{UVA}_{254}$ intensities decreased rapidly in the agricultural stream during the later phase of the event. Unlike the June event, relatively high $\mathrm{UVA}_{254}$ intensities were observed and decreased rapidly in the forest stream.

As illustrated by the representative example of $\mathrm{Pb}$ (Fig. 4), similar patterns were observed for temporal changes in the dissolved and total metal concentrations during the two precipitation events. In the agricultural steam total $\mathrm{Pb}$ concentrations changed dramatically over the course of both events, while overall magni- tudes and temporal changes in dissolved $\mathrm{Pb}$ concentrations were comparatively small. Although total $\mathrm{Pb}$ concentrations changed little in the forest stream during the June event, considerable changes were observed during the later phase of the August event (Fig. 4).

Relationships between $\mathrm{Pb}$ concentrations and TSS concentrations (as a measure of suspended sediments) or $\mathrm{UVA}_{254}$ (as a measure of dissolved organic matter) were compared for data from the June event (Fig. 5). In the agricultural stream, both dissolved and total $\mathrm{Pb}$ concentrations had significant positive relationships with either $\mathrm{UVA}_{254}$ intensities or TSS concentrations. Compared to the relationships found for dissolved $\mathrm{Pb}$, total $\mathrm{Pb}$ showed stronger relationships, particularly with TSS. In the forest stream, however, little temporal changes in all measured parameters resulted in insignificant relationships for all regression analyses.

One implication of our data is related to the rapid watershed responses to monsoon rainfalls, either small or extreme: we observed a rapid increase in the amount of suspended sediment carried by the agricultural 

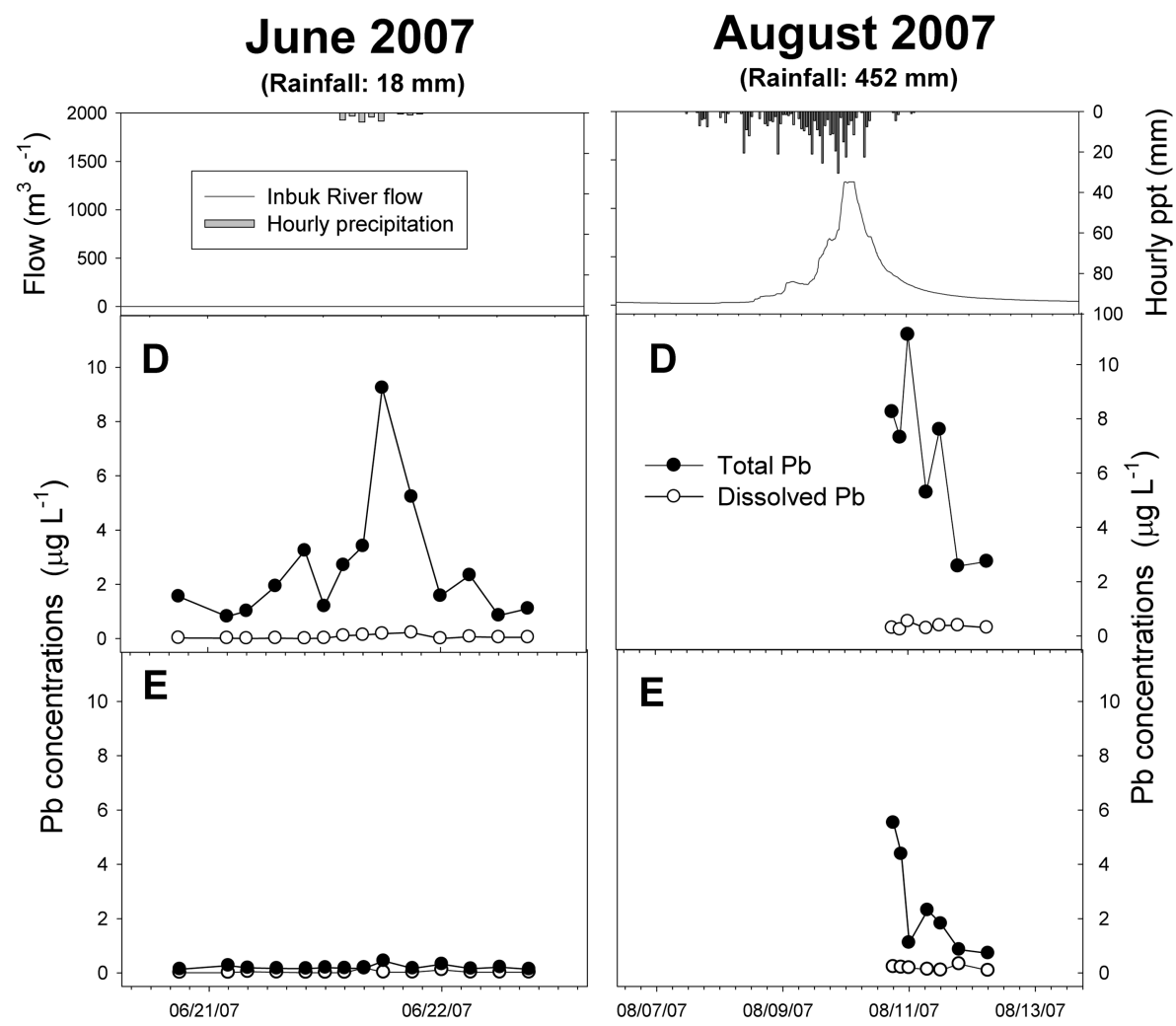

Fig. 4. Short-term changes in concentrations of dissolved and total $\mathrm{Pb}$ concentrations $\left(\mu \mathrm{g} \mathrm{L}{ }^{-1}\right)$ in the agricultural (site $\left.\mathrm{D}\right)$ and forest (site E) streams during two storm events.
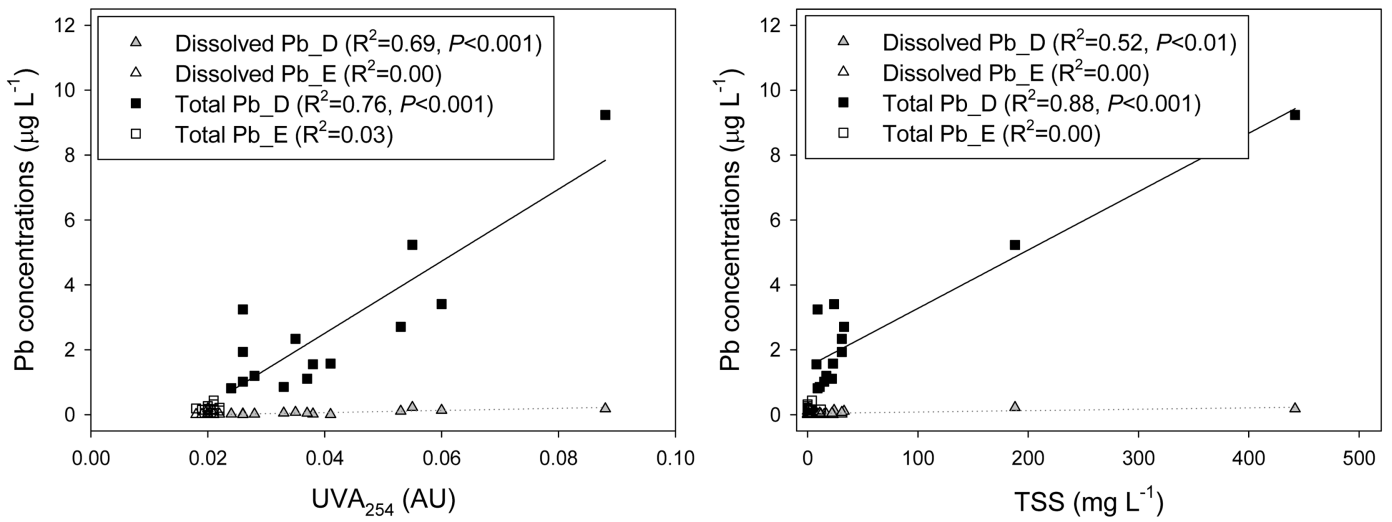

Fig. 5. Relationships between dissolved and total $\mathrm{Pb}$ concentrations and (a) $\mathrm{UVA}_{254}$ and (b) TSS concentrations in the agricultural (site D) and forest (site E) streams during the storm event in June 2007. The regression line through the plot indicates a significant relationship at $p<0.05$.

stream (site D), even for an event with only $18 \mathrm{~mm}$ of total rainfall that resulted in slight increases in stream flow and little changes in the river flow downstream (Fig. 3). For larger storm events, we would expect a larger amount of sediment carried to streams and trans- ported downstream, as indicated by the rapid decline during the later phase of the extreme event in August. In the future increases in channel bank erosion, along with surface erosion on deforested steep hillslopes, are likely to occur with an increased frequency of extreme 
hydrologic inputs (Asselman et al., 2003).

The results presented in this paper have relevance to evaluating the vulnerability of deforested steep mountainous watersheds to monsoon rainfalls because in areas where forests are replaced by agricultural lands, problems related to soil erosion and suspended sediment transport are exacerbated (Asselman et al., 2003; Park et al., 2010). Combined with current projections of changes in precipitation patterns and frequency of extreme events in Korea (Boo et al., 2006), this study highlights the need for more knowledge and increased understanding of patterns and processes involved in soil erosion, transport of suspended sediments and associated contaminants, and deposition processes in mountainous landscapes in Korea.

\section{IMPLICATIONS}

A number of recent studies have attempted to investigate the relationships between climate, human activity, and watershed nutrient export (eg., Kaushal et al., 2008; Han et al., 2009; Park et al., 2010). Unlike our study, these studies usually focused on single water quality issue, such as nitrogen export, in highly populated lowland watersheds using either monitoring or modeling approaches. To understand vulnerability of stream water chemistry to land use change in mountainous terrain, this study used a combination of survey approach and intensive storm samplings to examine spatiotemporal patterns in stream suspended solids and dissolved solutes.

Although our monitoring results should be assessed with caution due to limitations associated with sampling frequency and locations, the overall results suggest that seasonal differences and event-specific rapid changes in water quality are an important biogeochemical characteristic of streams in the studied mountainous watershed under mixed land use. During dry periods without significant storm events, concentrations of nutrients and total metals were generally lower than those under strong influence of agricultural runoff. During monsoon rainfall events, concentrations of total metals showed transient, but very rapid changes, particularly in the agricultural stream, in response to short-term changes in hydrologic flow and suspended sediments. The results emphasize the importance of suspended sediments accounting for much of the total concentration of metals with high sorption capacity such as Al, $\mathrm{Fe}, \mathrm{Mn}, \mathrm{Pb}$, and $\mathrm{Cu}$. Along with other human distur- bances including local agricultural practices, residential impacts, and localized erosion and construction activities that have had an increasing impact on surface water quality across the watershed, the conversion of steep forested hillslopes to arable lands has been suggested to increase the susceptibility of soil erosion and its off-site environmental impacts under increasing rainfall variability and extremes (Kim and Jung, 2007; Park et al., 2010). In addition to direct impacts on surface water quality, eroded sediments can have both short- and long-term ecological consequences in downstream rivers and lakes. Soil erosion and its off-site environmental impacts need to be taken into account in assessing climate-induced risks in mountainous watersheds.

\section{적 요}

토지 이용이 다변화된 산지 유역에서 몬순 강우에 의한 환경 영향을 평가하는데 필수적인 기초 자료를 확보하기 위해 수질의 계절간 비교와 강우사상 집중샘 플링의 방법을 활용하여 지표수 수질의 시공간적 변이 특성을 조사하였다. 유역 내 토지 이용을 반영하는 지 표수 9개 지점을 대상으로 건 - 우기 수질의 계절적 차 이를 비교하고, 2 회의 강우사상에 대해 산림과 농경지 하천 2 개 지점에서 집중 샘플링을 실시하였다. 대부분 의 지점에서 건기보다 우기에 전기전도도와 $\mathrm{Cl}^{-}$농도는 더 낮았으나, 총 금속 농도는 우기에 훨씬 더 높았다. 이는 우기에 늘어난 유량에 의해 용존 이온은 희석되 고, 토양 침식량은 증가됐기 때문인 것으로 보인다. 한 편 $18 \mathrm{~mm}$ 의 적은 강우 시에 산림 하천의 수질에서는 거의 변화가 보이지 않은 데 반해, 농경지 하천에서는 부유토사와 용존 물질 농도가 모두 가파른 변화를 보 였으며, $452 \mathrm{~mm}$ 의 많은 강우에 대해서는 농경지 하천 은 물론 산림 하천에서도 큰 수질 변화를 관찰할 수 있었다. 농경지 하천의 $\mathrm{Pb}$ 농도는 부유토사 농도와 높 은 양의 상관관계를 보였다. 제한된 샘플링 횟수와 조 사지점으로 인해 결과 해석에 신중을 기해야 하겠지만 , 전체 결과는 가파른 산지 유역에 농경지가 무분별하 게 확장되면 강우의 변동폭과 극단화가 심해질 경우 토양 침식과 그에 따른 환경 영향의 취약도가 증가할 것임을 시사한다.

\section{ACKNOWLEDGEMENTS}

This work was supported by the National Research 
Foundation of Korea funded by the Korean Government (KRF-2007-313-F00033 \& 2010-0015205). J.S. Owen was supported through the Brain Pool Program of the Korean Federation of Science \& Technology Societies. Chemical analysis of dissolved ions using ion chromatography was conducted at the Central Laboratory of Kangwon National University.

\section{REFERENCES}

Asselman, N. E. M., H. Middelkoop, and P. M. van Dijk, 2003: The impact of changes in climate and land use on soil erosion, transport and deposition of suspended sediment in the River Rhine. Hydrological Processes 17(16), 3225-3244.

Boo, K. O., W. T. Kwon, and H. J. Baek, 2006: Change of extreme events of temperature and precipitation over Korea using regional projection of future climate change. Geophysical Research Letter. 33, L01701.

Chang, H. J., J. Franczyk, and C. H. Kim, 2009: What is responsible for increasing flood risk? The case of Gangwon Province, Korea. Natural Hazards 48(3), 339-354.

Creed, J. T., C. A. Brockhoff, and T. D. Martin, 1994: Determination of Trace Elements in Waters and Wastes by ICPMS, Method 200.8 (Revision 5.4.). US Environmental Protection Agency.

Galy, V., C. France-Lanord, O. Beyssac, P. Faure, H. Kudrass, and F. Palhol, 2007: Efficient organic burial in the Bengal fan sustained by the Himalayan erosional system. Nature 450, 407-410.

Goldsmith, S. T., A. E. Carey, W. B. Lyons, S. J. Kao, T. Y. Lee, and J. Chen, 2008: Extreme storm events, landscape denudation, and carbon sequestration: Typhoon Mindulle, Choishui River, Taiwan. Geology 36(6), 483486.

Han, H., J. D. Allan, and D. Scavia, 2009: Influence of climate and human activities on the relationship between watershed nitrogen input and river export. Environmental Science \& Technology 43(6), 1916-1922.

Hilton, R. G., A. Galy, N. Hovius, M. C. Chen, M. J. Horng, and H. Chen, 2008: Tropical-cyclone-driven erosion of the terrestrial biosphere from mountains. Nature Geoscience 1, 759-762.

Horowitz, A. J., 1991: A Primer on Sediment-Trace Element Chemistry (2nd ed.). Chelsea, MI: Lewis Publishers.

Im, E. S., M. H. Kim, and W. T. Kwon, 2007: Projected change in mean and extreme climate over Korea from a double-nested regional climate model simulation. Journal of the Meteorology Society Japan 85, 717-732.

Kaushal, S. S., P. M. Groffman, L. E. Band, C. A. Shields, R. P. Morgan, M. A. Palmer, K. T. Belt, C. M. Swan, S. E. G. Findlay, and G. T. Fisher, 2008: Interaction between urbanization and climate variability amplifies watershed nitrate export in Maryland. Environmental Science \& Technology 42(16), 5872-5878.

Kim, B., K. S. Choi, C. G. Kim, U. H. Lee, and Y. H. Kim, 2000: Effects of the summer monsoon on the distribution and loading of organic carbon in a deep reservoir, Lake Soyang, Korea. Water Research 34(14), 3495-3504.

Kim, B. and S. Jung, 2007: Turbid storm runoffs in Lake Soyang and their environmental effect. Journal of Korean Society for Environmental Engineering 29, 1185-1190. (in Korean with English abstract).

Kim, B. J., R. H. Kripalani, J. H. Oh, and S. E. Moon, 2002: Summer monsoon rainfall patterns over South Korea and associated circulation features. Theoretical and Applied Climatology 72, 65-74.

Knapp, A. K., C. Beier, D. D. Briske, A. T. Classen, Y. Q. Luo, M. Reichstein, M. D. Smith, S. D. Smith, J. E. Bell, P. A. Fay, J. L. Heisler, S. W. Leavitt, R. Sherry, B. Smith, and E. Weng, 2008: Consequences of more extreme precipitation regimes for terrestrial ecosystems. Bioscience 58(9), 811-821.

Körner, C., 2005: Mountain systems. Ecosystems and Human Well-Being - Current State and Trends. Millennium Ecosystem Assessment Report Series, R. Hassan, R. Scholes, and N. Ash (Eds.), Washington, DC: Island Press, 681716.

Martin, J. M., and M. Meybeck, 1979: Elemental mass-balance of material carried by major world rivers. Marine Chemistry 7(3), 173-206.

Meybeck, M., P. Green, and C. Vorosmarty, 2001: A new typology for mountains and other relief classes. Mountain Research and Development 21(1), 34-45.

Milliman, J. D., and J. P. M. Syvitski, 1992: Geomorphic/ tectonic control of sediment discharge to the ocean: The importance of small mountainous rivers. Journal of Geology 100, 525-544.

Ministry of Environment of Korea. 2007. Management Strategies for Reducing Non-Point Source Pollution in the Lake Soyang Watershed (in Korean).

Park, J. H., L. Duan, B. C. Kim, M. J. Mitchell, and H. Shibata, 2010: Potential effects of climate change and variability on watershed biogeochemical processes and water quality in Northeast Asia. Environment International 36(2), 212-225.

Point, D., G. Bareille, D. Amouroux, H. Etcheber, and O. F. X. Donard, 2007 : Reactivity, interactions and transport of trace elements, organic carbon and particulate material in a mountain range river system (Adour River, France). Journal of Environmental Monitoring 9, 157167.

Shafer, M. M., J. T. Overdier, J. P. Hurley, D. Armstrong, and D. Webb, 1997: The influence of dissolved organic carbon, suspended particulates, and hydrology on the concentration, portioning and variability of trace metals in two contrasting Wisconsin watersheds (U.S.A.). Chemi- 
cal Geology 136, 71-97.

Shiller, A. M., 2003: Syringe filtration methods for examining dissolved and colloidal trace element distributions in remote field locations. Environmental Science and Technology 37(17), 3953-3957.
Viviroli, D., R. Weingartner, and B. Messerli, 2003: Assessing the hydrological significance of the world's mountains. Mountain Research and Development 23(1), 32-40.

Yanggu-Gun, 2008: The 47th Statistics Annual Report. (in Korean). 